\title{
Introduction on collective quarantine of close contacts of patients with COVID-19 for medical observation in China: from the perspective of frontline staff
}

\author{
Chenjie Dong ${ }^{1, \S}$, Yuan Tian, ${ }^{1, \S}$ Wenzhong $\mathrm{Xu}^{2}$, Jiangjiang $\mathrm{He}^{3, *}$, Duo Chen ${ }^{3}$, Jie Zhu ${ }^{4}$, Ping $\mathrm{Lu}^{4}$ \\ ${ }^{1}$ Jiading Health Affair Management Center, Shanghai, China; \\ ${ }^{2}$ Jiading District Health Commission, Shanghai, China; \\ ${ }^{3}$ Department of Health Policy Research, Shanghai Health Development Research Center (Shanghai Medical Information Center), Shanghai, China; \\ ${ }^{4}$ Malu Community Health Service Center, Jiading District, Shanghai, China.
}

SUMMARY The World Health Organization (WHO) has deemed coronavirus disease 2019 (COVID-19) to be a pandemic. The strict prevention and control measures taken by China have proven to be effective, creating a window of opportunity for other countries. The tracking and management of contacts of patients with COVID-19 are important components of prevention and control measures. This article briefly describes the placement of close contacts of patients with COVID-19 under collective quarantine for medical observation in China from the perspective of frontline staff. This article focuses on a community in the Jiading District of Shanghai to provide a reference for placement of close contacts of patients with COVID-19 under collective quarantine for medical observation in other countries and regions.

Keywords COVID-19, close contact, community, collective quarantine for medical observation

\section{Introduction}

The World Health Organization (WHO) deemed coronavirus disease 2019 (COVID-19) to be a pandemic (1); as of April 10, 2020, there were 1,521,252 confirmed cases and 92,798 deaths globally (2). Eight fundamental measures to respond to COVID-19 were cited by the WHO (3); identifying, tracking, and isolating contacts, a crucial task, was mentioned several times (3-5). On January 20, 2020, the Chinese Government classified COVID-19 as a category B infectious disease under the Law on the Prevention and Treatment of Infectious Diseases but it is regulating the disease as a category A infectious disease. COVID-19 was categorized as a quarantinable infectious disease pursuant to the Frontier Health and Quarantine Law (6). China implemented measures such as "Four Early Actions" (early detection, reporting, treatment, and isolation) and "Four Specifications" (the infected will be treated in dedicated facilities by senior medical professionals from around the country and with all necessary resources), and these strong prevention and control measures created a window of opportunity for other countries (7). The measures taken by China have proven to be effective (8-11). The tracking and management of contacts of patients with COVID-19 were both cited in the prevention and control suggestions offered by WHO $(12,13)$ and in Chinese guidelines on prevention and control measures (14).

Here, a town in Jiading District, Shanghai is cited as an example. This article briefly describes the placement of close contacts of patients with COVID-19 under collective quarantine for medical observation in China from the perspective of frontline staff.

\section{Overview of collective quarantine for medical observation}

Since the outbreak of COVID-19, the WHO and Chinese Government have issued several control and treatment protocols and implemented responses to prevent the transmission of the virus. Individual provinces and cities in China have initiated first-level public health emergency responses (15). The tracking and management of contacts of patients with COVID-19 is an important component of prevention and control measures. The WHO issued a guidance document on collective quarantine for medical observation (16), the Chinese Government published a series of related documents $(14,20,21)$, and Shanghai issued prevention and control documents based on the aforementioned documents that were particular to the region $(17-19,22)$. 
The documents provide guidance on the tracking and management of close contacts of patients, the selection of a site for collective quarantine, staff assignment and responsibilities, disinfection and protection, etc. Details on those documents are shown in Table 1.

2.1. Related departments, personnel, and their responsibilities

Individuals in China that need to be quarantined for medical observation and isolation efforts follow WHO guidelines. Tasks are mainly classified into management and coordination, medical and health care, and logistical support. Details on departments, personnel, and their responsibilities are shown in Table 2.

\subsection{Tasks}

Tasks at the quarantine sites are performed according to the required 14-day quarantine. Specific timepoints include the preparatory stage, preliminary observation (Day 1), intermediate observation (Day 2-Day 13), late observation (the afternoon of Day 13), and the day on which the individual is discharged from medical observation (Day 14). Staff should use self-protection and conduct regular disinfection according to related documents every time they come in contact with individuals under observation and they should enter and leave the quarantine area through specific entrances and exits. Detailed tasks are shown in Table 3.

\subsection{Procedures for referral and first aid}

When individuals under observation are in discomfort, they will be diagnosed and treated by general practitioners at the collective quarantine sites. If the individual needs to be referred, a Proof of Treatment Form from a Collective Quarantine Site for Medical Observation is needed. At that point, the community/ subdistrict is responsible for designating people and a vehicle to transport the individual. If the individual is suspected of having COVID-19 or under other special circumstances, community health center administrative staff at the quarantine site will contact a regional emergency center or fever clinic at a nearby medical facility, and designate people and a vehicle to transport the individual to the fever clinic along with regional first-aid personnel. Accompanying personnel should be in level-one protection and the transporting vehicle should be disinfected. In line with the protocol, if the individual is excluded as having COVID-19, the community/subdistrict will arrange a vehicle and personnel to pick the individual up. If the individual is confirmed as being infected, then the hospital that received the individual will refer the individual to the Shanghai Public Health Clinical Center for further treatment. The referral flowchart is shown in Figure 1.

\section{Factors that influence the effectiveness of medical observation}

From the perspective of frontline staff, there are 6 factors that may influence the effectiveness of medical observation of close contacts of patients with COVID-19:

i) The ability to lead and mobilize: The Chinese political system enables the Chinese Government to implement a series of powerful measures for epidemic prevention and control. Government at all levels and the entire society were mobilized, which was highly efficient (23). Hotels that met requirements were selected to serve as quarantine sites for medical observation, and the logistical management teams led by the government distributed and allocated resources in a standardized manner $(24,25)$.

ii) Inter-agency collaboration: Epidemic prevention and control is a task for society as a whole. It is not a job for the health department alone. A government at all levels approach is required (26). Staff at

Table 1. Documents related to placement of close contacts of patients with COVID-19 under collective quarantine for medical observation in China

\begin{tabular}{|c|c|c|}
\hline Date Issued & Issuing Institutions & File Name (Ref.) \\
\hline 2020.01 .28 & Shanghai Municipal Health Commission & $\begin{array}{l}\text { Notice on comprehensive health screening of people arriving in } \\
\text { Shanghai and isolation and observation (quarantine) of key groups for } \\
\text { prevention and control of COVID-19 in Shanghai (17). }\end{array}$ \\
\hline 2020.02 .07 & Shanghai Municipal People's Congress & $\begin{array}{l}\text { Decision to implement extensive efforts to prevent and control } \\
\text { COVID-19 (18). }\end{array}$ \\
\hline 2020.02 .11 & Shanghai Government & $\begin{array}{l}\text { Notice on further implementing strict individual prevention and control } \\
\text { measures (19). }\end{array}$ \\
\hline 2020.02 .29 & National Health Commission & $\begin{array}{l}\text { Notice on the further standardization and enhancement of disinfection } \\
\text { efforts amid the COVID-19 epidemic }(20) \text {. }\end{array}$ \\
\hline 2020.03 .04 & National Health Commission & $\begin{array}{l}\text { Notice on the issuance of the Diagnosis and Treatment Protocol for } \\
\text { COVID-19 }\left(7^{\text {th }} \text { ed., draft }\right)(21) \text {. }\end{array}$ \\
\hline 2020.03 .07 & National Health Commission & $\begin{array}{l}\text { Notice on the issuance of the Protocol for Prevention and Control of } \\
\text { COVID-19 }\left(6^{\text {th }} \text { ed.) }(14) .\right.\end{array}$ \\
\hline 2020.03 .13 & Shanghai Municipal Health Commission & $\begin{array}{l}\text { Notice on the issuance of the Shanghai Protocol for Prevention and } \\
\text { Control of COVID-19 }\left(5^{\text {th }} \text { ed.) }(22) \text {. }\right.\end{array}$ \\
\hline
\end{tabular}


Table 2. Departments, personnel, and corresponding responsibilities at the collective quarantine sites for medical observation of close contacts of patients with COVID-19

\begin{tabular}{|c|c|c|c|}
\hline Category of tasks & Related Department & Personnel (code) & Responsibilities \\
\hline \multirow[t]{3}{*}{$\begin{array}{l}\text { Management and } \\
\text { coordination }\end{array}$} & Government departments & $\begin{array}{l}\text { Community/subdistrict } \\
\text { administrative staff }(\mathrm{A})\end{array}$ & $\begin{array}{l}\text { Organize, manage and coordinate all persons sent by each } \\
\text { department and assign tasks; better allocate materials; deal } \\
\text { with all emergencies. }\end{array}$ \\
\hline & \multirow[t]{2}{*}{$\begin{array}{l}\text { Health Administration } \\
\text { department }\end{array}$} & Health administrative staff (B) & $\begin{array}{l}\text { Assist A to manage and coordinate personnel within the health } \\
\text { system and to better allocate health resources. }\end{array}$ \\
\hline & & $\begin{array}{l}\text { Health supervision and } \\
\text { enforcement personnel }(\mathrm{C})\end{array}$ & $\begin{array}{l}\text { Supervise health and enforce the law, evaluate areas of } \\
\text { isolation; evaluate pollutants and sewage treatment. }\end{array}$ \\
\hline \multirow[t]{7}{*}{$\begin{array}{l}\text { Medical and } \\
\text { health care }\end{array}$} & \multirow[t]{7}{*}{$\begin{array}{l}\text { Medical and health care } \\
\text { facilities }\end{array}$} & $\begin{array}{l}\text { Community health center } \\
\text { administrative staff (D) }\end{array}$ & $\begin{array}{l}\text { Manage and coordinate the quarantine site, arrange food and } \\
\text { materials, assign tasks to site staff; convey information on } \\
\text { individuals under observation and arrange material reserves } \\
\text { and supplies. }\end{array}$ \\
\hline & & General practitioner $(\mathrm{E})$ & $\begin{array}{l}\text { Receive and instruct individuals under observation; perform } \\
\text { medical evaluation and routine diagnosis and treatment of } \\
\text { individuals under observation; train the staff and individuals } \\
\text { under observation in the prevention and control of the } \\
\text { epidemic; disinfect contaminated areas. }\end{array}$ \\
\hline & & Psychologists (F) & $\begin{array}{l}\text { Provide psychological assessment, counseling, and treatment } \\
\text { to individuals under observation. }\end{array}$ \\
\hline & & Public health physicians (G) & $\begin{array}{l}\text { Perform an infection risk assessment and epidemiological } \\
\text { investigation of individuals under observation; disinfect } \\
\text { contaminated areas. }\end{array}$ \\
\hline & & Nurses $(\mathrm{H})$ & $\begin{array}{l}\text { Provide care to individuals under observation, train staff and } \\
\text { the individuals under observation in the prevention and control } \\
\text { of the epidemic; prepare disinfectants and instruct disinfection } \\
\text { workers to thoroughly disinfect public areas and partially } \\
\text { contaminated areas; dispose of medical waste and provide } \\
\text { related instructions. }\end{array}$ \\
\hline & & Pharmacists (I) & Instruct individuals under observation in taking medication. \\
\hline & & CDC professionals $(\mathrm{J})$ & $\begin{array}{l}\text { Collect, analyze, and transmit information on individuals } \\
\text { under observation; guide quarantine sites to prevent and } \\
\text { control the epidemic. }\end{array}$ \\
\hline \multirow[t]{9}{*}{ Logistical support } & Fire department & Firemen $(\mathrm{K})$ & Evaluate and supervise fire safety and respond to fires. \\
\hline & $\begin{array}{l}\text { Public security and civil } \\
\text { affairs authorities }\end{array}$ & Policemen (L) & Evaluate and ensure safety. \\
\hline & Security department & Security staff (M) & $\begin{array}{l}\text { Provide safety; keep order in quarantine sites; deliver } \\
\text { materials like daily essentials and food. }\end{array}$ \\
\hline & $\begin{array}{l}\text { Foreign affairs } \\
\text { department }\end{array}$ & Interpreters $(\mathrm{N})$ & $\begin{array}{l}\text { Interpret, communicate, and coordinate; convey information } \\
\text { to foreigners. }\end{array}$ \\
\hline & \multirow[t]{3}{*}{ Sanitation and cleaning } & Cleaner $(\mathrm{O})$ & Clean surroundings and rooms, dispose of waste collectively. \\
\hline & & Disinfection worker $(\mathrm{P})$ & $\begin{array}{l}\text { Disinfect public areas, partially contaminated areas, and } \\
\text { vehicles. }\end{array}$ \\
\hline & & Sanitation worker (Q) & Collect and transport waste and medical waste. \\
\hline & Social organizations & Volunteers (R) & $\begin{array}{l}\text { Register information on and communicate with individuals } \\
\text { under observation; register and report on the needs of } \\
\text { individuals under observation and give feedback. }\end{array}$ \\
\hline & Hotels & Hotel staff (S) & Operate hotels and ensure the supply of materials. \\
\hline
\end{tabular}

quarantine sites consisted of agency officials, health administrators, medical personnel, firemen, policemen, security personnel, foreign affair personnel, sanitation workers, volunteers, and hotel staff. This inter-agency collaboration contributed to the coherence of epidemic prevention and control.

iii) The establishment of health emergency teams and funding and material support: An experienced and well-trained team can calmly deal with a public health emergency and play a major role. The development and continuous training of health emergency teams can improve their capabilities. Abundant funding and materials can ensure the consistency of collective quarantine under medical observation and help medical personnel to perform tasks in an orderly manner.

$i v)$ Efficient transmission of information: Convenient and efficient transmission and integration of information facilitates inter-agency collaboration, promotes efficiency, and facilitates the effective and reasonable allocation of human resources and materials to ensure highly efficient epidemic prevention and control. Valid news can prevent the spread of rumors and reduce risks caused by misinformation (26).

v) The psychological status of individuals under observation: Individuals under observation can be affected by their physical health or by psychological 
Table 3. Efforts at sites for medical observation of close contacts of patients with COVID-19

\begin{tabular}{|c|c|c|c|}
\hline Time & Efforts & Details & Executor \\
\hline \multirow[t]{5}{*}{ Preparatory stage } & Location selection & $\begin{array}{l}\text { Select hotels that meet requirements as collective quarantine sites for } \\
\text { medical observation. }\end{array}$ & A, B \\
\hline & Evaluation & Evaluate pollutants, sewage treatment, and quarantine areas. & $\mathrm{C}$ \\
\hline & & Fire safety assessment. & $\mathrm{K}$ \\
\hline & & Security assessment. & $\mathrm{L}$ \\
\hline & Training & Provide preliminary training to all staff. & $\mathrm{D}, \mathrm{E}, \mathrm{F}, \mathrm{H}$ \\
\hline \multirow[t]{18}{*}{ Day 1} & Collection of information & Collect and confirm information on individuals under observation. & $\mathrm{D}$ \\
\hline & Accommodations & Arrange rooms and order meals for individuals under observation. & $\mathrm{D}$ \\
\hline & Task assignment & Assign the task of receiving individuals under observation. & $\mathrm{D}$ \\
\hline & $\begin{array}{l}\text { Reception of individuals } \\
\text { for observation }\end{array}$ & $\begin{array}{l}\text { Contact medical personnel who will transfer individuals and confirm } \\
\text { information. }\end{array}$ & $\mathrm{E}$ \\
\hline & & $\begin{array}{l}\text { Inform close contacts of patients about issues related to collective quarantine } \\
\text { for medical observation. }\end{array}$ & $\mathrm{E}$ \\
\hline & & $\begin{array}{l}\text { Have individuals sign a Consent to Medical Observation Form for close } \\
\text { contacts of patients with COVID-19 in Shanghai and the Shanghai Jiading } \\
\text { Form for Placement in Collective Quarantine. }\end{array}$ & $\mathrm{E}$ \\
\hline & & $\begin{array}{l}\text { Inform people under medical observation at quarantine sites about self- } \\
\text { protection and disinfection and provide friendly reminders about the } \\
\text { psychological support hotline. }\end{array}$ & $\mathrm{E}$ \\
\hline & Evaluation & $\begin{array}{l}\text { Preliminary evaluation of infection risks: perform an epidemiological } \\
\text { investigation. }\end{array}$ & $\mathrm{E}$ \\
\hline & & Disease evaluation: inquire about clinical symptoms and medical history. & $\mathrm{E}$ \\
\hline & & Evaluate the mental health of individuals under observation. & $\mathrm{F}$ \\
\hline & Check-in guidance & $\begin{array}{l}\text { Instruct individuals under observation to enter rooms via a specific entryway } \\
\text { and describe things, equipment, and devices in the room and how to use } \\
\text { them. }\end{array}$ & $\mathrm{E}$ \\
\hline & & $\begin{array}{l}\text { Inform individuals of how to take their temperature and train them in self- } \\
\text { protection and disinfection. }\end{array}$ & $\mathrm{E}$ \\
\hline & $\begin{array}{l}\text { Documentation of } \\
\text { information }\end{array}$ & $\begin{array}{l}\text { Record information on individuals under observation and complete the } \\
\text { health status information registration form. }\end{array}$ & $\mathrm{E}$ \\
\hline & $\begin{array}{l}\text { Reassessment of infection } \\
\text { risk }\end{array}$ & $\begin{array}{l}\text { Communicate by phone, confirm and supplement the individual's } \\
\text { epidemiological history. }\end{array}$ & G \\
\hline & Routine communication & $\begin{array}{l}\text { Communicate by phone and ascertain the individual's living conditions and } \\
\text { report their needs to D. }\end{array}$ & $\mathrm{R}$ \\
\hline & $\begin{array}{l}\text { Taking an individual's } \\
\text { temperature }\end{array}$ & Take the individual's temperature twice a day. & $\mathrm{E}$ \\
\hline & Waste disposal & $\begin{array}{l}\text { Household waste of asymptomatic individuals under observation can be } \\
\text { disposed of as general household waste after disinfection; that of individuals } \\
\text { with symptoms should be disposed of as infective medical waste. }\end{array}$ & $\mathrm{O}, \mathrm{Q}, \mathrm{G}, \mathrm{H}$ \\
\hline & Environment disinfection & Train disinfection workers to disinfect surroundings. & $\mathrm{P}$ \\
\hline \multirow[t]{4}{*}{ Day 2-Day 13} & Routine communication & $\begin{array}{l}\text { Communicate by phone and ascertain the individual's living conditions and } \\
\text { report their needs to D. }\end{array}$ & $\mathrm{R}$ \\
\hline & Evaluation and observation & $\begin{array}{l}\text { Evaluate infection risk and prior disease risk and deal with those risks, } \\
\text { inspect rooms, and take the individual's temperature. }\end{array}$ & $\mathrm{E}$ \\
\hline & $\begin{array}{l}\text { Disease diagnosis and } \\
\text { treatment }\end{array}$ & $\begin{array}{l}\text { Diagnose and treat individuals with a risk of infection and disease, and } \\
\text { refer them if treatment is not feasible (see the Referral flowchart for close } \\
\text { contacts under medical observation) }\end{array}$ & $\mathrm{E}$ \\
\hline & Psychological counseling & Provide psychological counseling to depressed individuals. & $\mathrm{F}$ \\
\hline \multirow[t]{3}{*}{ Day 13} & $\begin{array}{l}\text { Preliminary evaluation } \\
\text { before discharging }\end{array}$ & Inquire about medical history and take the individual's temperature. & $\mathrm{E}$ \\
\hline & Providing information & Deliver a Notification of Discharge from Isolation. & $\mathrm{E}$ \\
\hline & $\begin{array}{l}\text { Documentation of } \\
\text { information }\end{array}$ & $\begin{array}{l}\text { Complete the Notification of Discharge from Medical Observation for Close } \\
\text { Contacts of Patients with COVID-19 in Shanghai. }\end{array}$ & $\mathrm{E}$ \\
\hline \multirow[t]{5}{*}{ Day 14} & $\begin{array}{l}\text { Re-evaluation before } \\
\text { discharge }\end{array}$ & Ask individuals about their medical history and take their temperature. & $\mathrm{E}$ \\
\hline & $\begin{array}{l}\text { Discharge from medical } \\
\text { observation }\end{array}$ & $\begin{array}{l}\text { Give out Discharging Notification to Close Contacts of Patients with } \\
\text { COVID-19 in Shanghai and one mask to those who are healthy. }\end{array}$ & $\mathrm{E}$ \\
\hline & Guidance upon departure & Instruct individuals to leave via specific exits. & $\mathrm{E}$ \\
\hline & Final disinfection & Perform a final disinfection of the room. & $\mathrm{E}$ \\
\hline & Information documentation & $\begin{array}{l}\text { Record related information on Registration Log of Medical Observation } \\
\text { Discharging. }\end{array}$ & $\mathrm{E}$ \\
\hline
\end{tabular}




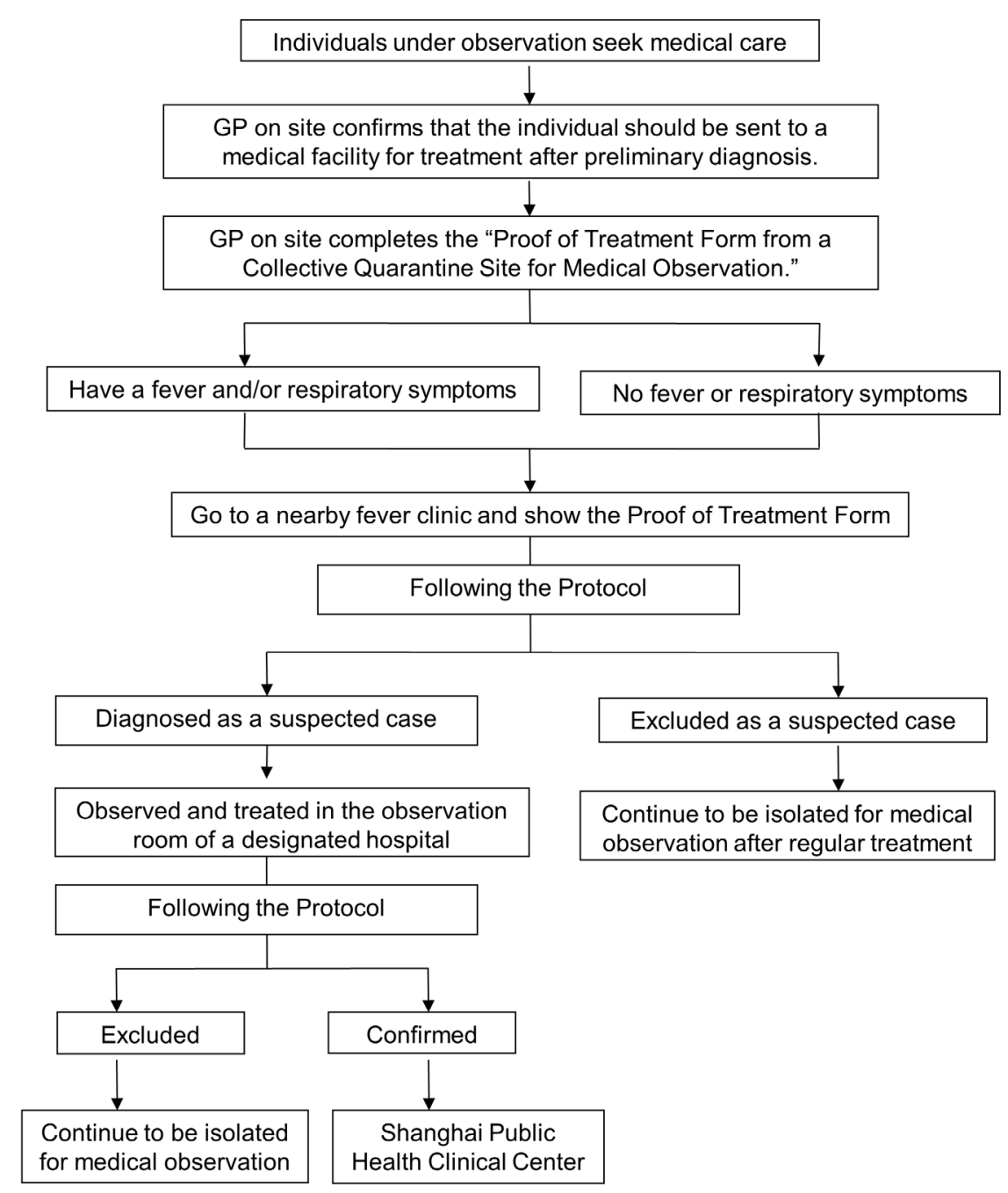

Figure 1. Referral flowchart for close contacts of patients with COVID-19 under medical observation in Shanghai.

factors. The diversity of needs and whether those needs are met have an impact on individuals, including the risk of disease during observation and mental health. During the preliminary stage of observation, a psychological assessment should be performed on individuals under observation as early as possible, and effective interventions should be implemented to help facilitate medical observation.

vi) Attention to key groups: During medical observation, more attention should be paid to key groups (such as children, the elderly, pregnant women, patients with chronic diseases, and patients with particular diseases). They have lower immunity and need special care. An early assessment of the risk of infection and disease should be performed for these groups, and effective interventions should be promptly implemented to help facilitate medical observation.

According to information on the distribution of cases of COVID-19 from the Chinese Center for Disease Control and Prevention (27), the number of cases tended to decline in mid-February in most regions of China. As of March 31, 2020, there were 81,554 confirmed cases, 76,238 cases cured, and 3,312 deaths
(28). Currently, important results have been achieved by China's phased epidemic prevention and control. Local transmission of COVID-19 has basically been blocked on the Chinese mainland. The overall status of the epidemic is improving (29). However, there is a possibility of recurrence, and attention should be paid to cured patients who later test positive for the virus, patients with false-negative results, asymptomatic carriers, and new patients (30). Overseas, the pandemic is rapidly spreading, bring greater pressure on China to regulate imported cases of COVID-19. More strict management of travelers arriving in China is needed (31). When individuals who have already arrived in China are placed under medical observation, attention must be paid to different cultures and different values in order to avoid unnecessary conflicts and to sustain the effectiveness of medical observation. In the long run, attention should be paid to post-traumatic stress disorder (PTSD) among individuals under observation. A psychological support hotline was instituted and guidelines on psychological support, counseling, and crisis interventions were issued in China to alleviate the psychological harms caused by the epidemic and to 
actively prevent, alleviate, and control the social effects of the epidemic on the mental state of those affected (32-36). These efforts aim to identify high-risk groups and avoid the incidence of extreme events.

\section{Acknowledgements}

This paper was supported by grants from the Shanghai Jiading District Health Commission for a "Study of the community strategies for prevention and control of major infectious diseases in Jiading District" (Project number: 2020JDHP12) (to Chenjie Dong, Yuan Tian and Ping Lu) and the China Medical Board Collaborating Project "Establishing Health Policy Transformation Network of China (Project number: CMB-CP 14-190)" (to Jiangjiang He and Duo Chen).

\section{References}

1. World Health Organization. WHO Director-General's opening remarks at the media briefing on COVID-19 11 March 2020. https://www.who.int/dg/speeches/detail/ who-director-general-s-opening-remarks-at-the-mediabriefing-on-covid-19---11-march-2020 (accessed March 11, 2020).

2. World Health Organization. WHO. Coronavirus disease (COVID-2019) situation reports. https://www.who.int/ emergencies/diseases/novel-coronavirus-2019/situationreports/ (accessed March 29, 2020).

3. World Health Organization. WHO Director-General's opening remarks at the media briefing on COVID-19 9 March 2020. https://www.who.int/dg/speeches/detail/ who-director-general-s-opening-remarks-at-the-mediabriefing-on-covid-19---9-march-2020 (accessed March 9, 2020).

4. World Health Organization. WHO Director-General's opening remarks at the media briefing on COVID-19 - 25 March 2020.https://www.who.int/dg/speeches/detail/whodirector-general-s-opening-remarks-at-the-media-briefingon-covid-19---25-march-2020 (accessed March 25, 2020).

5. World Health Organization. WHO Director-General's opening remarks at the media briefing on COVID-19 27 March 2020. https://www.who.int/dg/speeches/detail/ who-director-general-s-opening-remarks-at-the-mediabriefing-on-covid-19---27-march-2020 (accessed March 27, 2020).

6. National Health Commission. Announcement by the National Health Commission of the People's Republic of China. No.1 2020. http://www.nhc.gov.cn/xcs/zhengcw j/202001/44a3b8245e8049d2837a4f27529cd386.shtml (accessed January 20, 2020). (in Chinese)

7. World Health Organization. WHO-AUDIO Executive Board EB146 Coronavirus Briefing. https://www.who. int/docs/default-source/coronaviruse/transcripts/whoaudio-executive-board-eb146-coronavirus-briefingscript-04feb2020-final.pdf?sfursn=70a66dfc_2 (accessed February 4, 2020).

8. Bureau of Disease Prevention and Control. Report of the WHO-China Joint Mission on Novel Coronavirus Disease 2019 (COVID-19) is issued. http://www.nhc.gov.cn/jkj/s3 578/202002/87fd92510d094e4b9bad597608f5cc2c.shtml ?wYNOrhhjiR4y=1582949699287 (accessed February 29,
2020). (in Chinese)

9. Department of International Cooperation. Transcript of a Press Conference of the WHO-China Joint Mission on COVID-19. http://www.nhc.gov.cn/gjhzs/s3578/202002 /1fa99f55972740f681d47cde0d1b2522.shtml (accessed February 24, 2020). (in Chinese)

10. World Health Organization. WHO Director-General's opening remarks at the media briefing on COVID-19 - 28 February. 2020.https://www.who.int/dg/speeches/ detail/who-director-general-s-opening-remarks-at-themedia-briefing-on-covid-19---28-february-2020 (accessed February 28, 2020).

11. World Health Organization. WHO Director-General's opening remarks at the media briefing on COVID-19 20 March 2020. https://www.who.int/dg/speeches/detail/ who-director-general-s-opening-remarks-at-the-mediabriefing-on-covid-19---20-march-2020 (accessed March 20, 2020).

12. World Health Organization. WHO Director-General's opening remarks at the media briefing on COVID-19 6 March 2020. https://www.who.int/dg/speeches/detail/ who-director-general-s-opening-remarks-at-the-mediabriefing-on-covid-19---6-march-2020 (accessed March 6, 2020).

13. World Health Organization. WHO Director-General's opening remarks at the mission briefing on COVID-19 - 26 February. 2020.https://www.who.int/dg/speeches/ detail/who-director-general-s-opening-remarks-atthe-mission-briefing-on-covid-19---26-february-2020 (accessed February 26, 2020).

14. National Health Commission. Notice from the National Health Commission on the issuance of the Protocol for Prevention and Control of COVID-19 (6 $6^{\text {th }}$ ed.). http:// www.nhc.gov.cn/xcs/zhengcwj/202003/4856d5b0458141f a9f376853224d41d7.shtml (accessed March 7, 2020). (in Chinese)

15. Huanqiu. Latest news! 22 provinces and cities initiate a primary public health emergency response. https://china. huanqiu.com/article/9CaKrnKp3Vd (accessed January 25, 2020). (in Chinese)

16. World Health Organization. Considerations for quarantine of individuals in the context of containment for coronavirus disease (COVID-19). https://www.who.int/publicationsdetail/considerations-for-quarantine-of-individuals-in-thecontext-of-containment-for-coronavirus-disease-(covid-19) (accessed March19, 2020).

17. Notice on comprehensive health screening of people arriving in Shanghai and isolation and observation (quarantine) of key groups for prevention and control of COVID-19 in Shanghai. https://hpq.sh.gov.cn/zw/009002/ 009002016/009002016004/009002016004004/20200225/ 7b0d41ae-9bal-465b-9892-e08c320d5a23.html (accessed January 28, 2020). (in Chinese)

18. Shanghai Government website. Decision of the Shanghai Municipal People's Congress to implement extensive efforts to prevent and control COVID-19. http://www.shanghai. gov.cn/nw2/nw2314/nw32419/nw48516/nw48545/ nw48635/u26aw63497.html (accessed February 7, 2020). (in Chinese)

19. Shanghai Government website. Notice from the Shanghai Government on further implementing strict individual prevention and control measures. http://www.shanghai.gov. cn/nw2/nw2314/nw32419/nw48516/nw48545/nw48635/ u26aw63661.html (accessed February 11, 2020). (in Chinese) 
20. National Health Commission. Notice on the further standardization and enhancement of disinfection efforts amid the COVID-19 epidemic. http://www.nhc.gov.cn/ xcs/zhengcwj/202002/d1ae51c7899d4faaa763a2e67ebbd 2e5.shtml (accessed February 29, 2020). (in Chinese)

21. General Office of the National Health Commission. Notice on issuance of the Diagnosis and Treatment Protocol for COVID-19 ( $7^{\text {th }}$ ed., draft). http://www.nhc.gov.cn/xcs/zhen gcwj/202003/46c9294a7dfe4cef80dc7f5912eb1989.shtml (accessed March 3, 2020). (in Chinese)

22. Shanghai Municipal Health Commission. Notice on the issuance of the Shanghai Protocol for Prevention and Control of COVID-19 (5 $5^{\text {th }}$ ed.). http://wsjkw.sh.gov.cn/jbf k2/20200313/19d2f5ed7e174e0db5b895da0ale0b20.html (accessed February 24, 2020). (in Chinese)

23. People's Daily Online. The unrivalled advantage of the system of socialism with Chinese characteristics. http:// world.people.com.cn/n1/2020/0315/c1002-31632120.html (accessed March 15, 2020). (in Chinese)

24. General Office of the National Health Commission. Notice of the General Office of the National Health Commission on enhancing efforts by primary care facilities to prevent and control COVID-19. http://www.gov.cn/zhengce/ zhengceku/2020-01/27/content_5472401.htm (accessed January 26, 2020). (in Chinese)

25. Chinese Thoracic Society, Chinese Society of General Practice, Chinese Association of Chest Physicians, et al. Expert recommendations for the prevention and control of SARS-CoV-2 virus infection in primary care (First Edition), Chinese Journal of General Practitioners. 2020; $19: 175-192$. (in Chinese)

26. World Health Organization. Munich Security Conference. https://www.who.int/dg/speeches/detail/munich-securityconference (accessed February 15, 2020).

27. Chinese Center for Disease Control and Prevention. Prevalence and distribution of COVID-19. http://2019ncov. chinacdc.cn/2019-nCoV/ (accessed January 26, 2020). (in Chinese)

28. National Health Commission. The prevalence of COVID-19 as of 12 AM on March 31, 2020. https://www.xuexi.cn/ lgpage/detail/index.html?id=1939773170044809532\&ite $m i d=1939773170044809532$ (accessed April 1, 2020). (in Chinese)

29. CCTV. National Health Commission: China's epidemic prevention and control achieved important results in stages. http://news.cctv.com/2020/03/13/ ARTIYYzn3IrVYHkGsZRBRtwa200313.shtml (accessed March 13, 2020). (in Chinese)

30. The Paper. Alerts: Nanshan Zhong suggests maintaining the current prevention and control measures and Wenhong Zhang emphasizes the necessity of strict prevention and control measures. https://www.thepaper.cn/newsDetail_ forward 6732253 (accessed March 28, 2020). (in Chinese)

31. CNR. Premier Li Keqiang held a meeting of the leaders of China's COVID-19 response, stressing measures to prevent the resurgence of the epidemic domestically and calling for further efforts to prevent imported cases arriving by land and water. http://china.cnr.cn/news/20200327/ t20200327 525031811.shtml (accessed March 27, 2020). (in Chinese)

32. Bureau of Disease Prevention and Control, National Health Commission. Notice on the issuance of guidelines for emergency psychological interventions related to the COVID-19 epidemic. http://www.nhc.gov.cn/xcs/zhengc wj/202001/6adc08b966594253b2b791be5c3b9467.shtml (accessed January 26, 2020). (in Chinese)

33. Bureau of Disease Prevention and Control, National Health Commission. Notice on the institution of a hotline to provide psychological support in response to the epidemic. http://www.nhc.gov.cn/xcs/zhengcwj/202002 /8f832e99f446461a87fbdceecelfdb02.shtml (accessed February 2, 2020). (in Chinese)

34. Bureau of Disease Prevention and Control, National Health Commission. Notice on the issuance of guidelines for a psychological support hotline during the COVID-19 epidemic. http://www.nhc.gov.cn/xcs/zhengcwj/202002/ f389f20cc1174b21b981ea2919beb8b0.shtml (accessed February 7, 2020). (in Chinese)

35. General Office of the National Health Commission. Notice on enhancing psychological support and social services in relation to prevention and control of COVID-19. http:// www.nhc.gov.cn/xcs/zhengcwj/202003/a9b0bcb3bb74452 98c480c5003c51d6d.shtml (accessed March 5, 2020). (in Chinese)

36. Bureau of Disease Prevention and Control, National Health Commission. Notice on the issuance of a plan for psychological counseling of people affected by COVID-19. http://www.nhc.gov.cn/xcs/zhengcwj/202003/0beb22634f8a $4 a 48 a e c f 405 c 289 f c 25$ e.shtml (accessed March 18, 2020). (in Chinese)

Received April 16, 2020; Revised April 29, 2020; Accepted May 7, 2020.

${ }^{\S}$ These authors contributed equally to this work.

*Address correspondence to:

Jiangjiang He, Shanghai Health Development Research Center (Shanghai Medical Information Center), No.1477 Beijing (W) Road, Jing'an District, Shanghai, China 200040.

E-mail: hejiangjiang@shdrc.org

Released online in J-STAGE as advance publication May 9, 2020 . 